\title{
THE USE OF E-BUSINESS IN SERBIAN TRAVEL AGENCIES: DEVELOPMENT OF THE EBUSTOUR MODEL
}

\author{
Ivana Mišković, Fakultet za sport i turizam, Novi Sad \\ Jelica Marković \\ Gordana Đurić, Srednja škola „Svetozar Miletić, Novi Sad
}

\begin{abstract}
Conducting business by using the internet has become an everyday occurrence in all spheres of economy, as well as in the tourism sector. There is an increasing number of agencies in the world that conduct their business almost completely on-line. The aim of this research was to examine what characterizes the process of implementation of electronic business with tourist agencies in Serbia on the sample of 65 companies, and whether it differs depending on certain business characteristics. For that purpose, EBusTour model was developed that consists of 14 items grouped into four categories: online communication, online promotion, impact on sales and working hours reduction vs. sales improvement. As far as tourist agencies in Serbia are concerned, the results of the application of EBusTour model show that the most common activity in this field is basic online promotion (website implementation), followed by effects on sales. The paper also investigates whether there are differences in e-business implementation in relation to the characteristics such as: years in business, the type of licence (tour operator or sales agent) and the type of market (incoming, outgoing or combined).
\end{abstract}

Keywords: E-business, Travel agencies, EBusTour model, Serbia

\section{ELEKTRONSKO POSLOVANJE U SRPSKIM TURISTIČKIM AGENCIJAMA: RAZVOJ EBUSTOUR MODELA}

Sažetak

Poslovanje uz pomoć interneta postalo je svakodnevna pojava u svim sferama savremene ekonomije, pa i turističkog sektora. Sve je veći broj turističkih agencija koje gotovo u potpunosti posluju onlajn. Cilj ovog istraživanja je da se ispitaju karakteristike procesa implementacije elektronskog poslovanja u srpskim turističkim agencijama, na uzorku od 65 preduzeća, i otkrivanje povezanosti tog procesa sa poslovnim karakteristikama svakog od njih. U tu svrhu kreiran je EbusTour model koji sadrži 14 ajtema podeljena u četiri kategorije: „onlajn komunikacija”, „onlajn promocija“, „uticaj na prodaju“ $\mathrm{i}$ „redukcija radnog vremena nasuprot unapređenju prodaje“. Kada su u pitanju turističke agencije u Srbiji, primena EbusTour modela pokazuje da je najučestalja aktivnost na ovom polju bazična onlajn promocija (implementacija veb sajta), koju prate aktivnosti iz kategorije „uticaj na prodaju“. U radu su, takođe, prikazane 
međusobne povezanosti procesa implementacije elektronskog poslovanja sa poslovnim karakteristikama preduzeća, kao što je broj godina poslovanja, vrsta licence (organizator putovanja ili posrednik) i ciljno tržište (receptivne, inicijativne ili mešovite agencije).

Ključne reči: elektronsko poslovanje, turističke agencije, EBusTour model, Srbija

\section{Introduction}

In recent years, the role of traditional travel mediators (tour-operators and travel agents) has changed due to the introduction of the internet and e-commerce technologies. As the suppliers believe they no longer need a mediator to sell their products as direct marketing is cutting into the business of traditional agencies (Tsai, Huang, \& Lin, 2005). On the other hand, consumers are becoming increasingly technologically literate and are, therefore, more selective and knowledgeable about purchasing online. For young, educated, independent and budget-limited travelers used to using the internet to get instant information, the idea of waiting for somebody else to book their trip is becoming increasingly rarer. Only a third of internet users nowadays prefer dealing with a travel agent than a website (etourismnewsletter, 2002). However, a handful of travel agencies have proven that, even if one can find good deals oneself, there are still instances where a travel agency can find even a better one (Travel Agent, 2012). In practice, consumers increasingly bring printouts from the Internet to travel agencies and request travel agencies to either match the offer they hold or to do the actual booking for them (Buhalis \& Licata, 2001). The role of travel agents has changed from taking reservations to offering advice and consultancy services for individuals and corporations (Chu, 2001), mediators already conduct business as information brokers, processors of payment/money transactions, advice providers and value-added service providers (managing special requirements, needs, policies etc.). Many traditional travel agencies now have full-service websites so that the client can get the convenience of self-serve online booking with the benefit of talking to a real person when needed.

Despite the fear that they can completely disappear from the market, according to Bush (2000; 2001), the role of an agent in tourism industry may even increase, not decrease. The key strength of travel agents can be found in their ability to provide personal information and advice to travellers and recognize the adoption of IT in the business processes as one of the key success factors (Suarez, Diaz, \& Vazquez, 2007). Online travel agencies are increasing their competitiveness using quality as a strategic element (Roger-Monzo, Marti-Sanchez, \& Guijarro-Garcia, 2015). IATA airline members, booking system providers and GDSs have all implemented the use of new technologies in their business (Andreu, Aldas, Bigne, \& Mattila, 2010). WTO (2001) also indicated that electronic business offers SMTEs (Small and Medium Tourism Enterprises) the opportunity to undertake their business in new and more cost-effective ways. OECD (2000) revealed that the advent of internet-based electronic commerce offers considerable opportunities for companies to expand their customer base, enter new product markets and rationalise their business.

This paper outlines the development of a research instrument - EBusTour, which is designed to measure tendencies in e-business implementation in travel agencies. The authors also investigated whether there are differences in e-business use among travel agencies, taking into account the characteristics of some agencies such as: years in business, the type of licencing (tour-operator or sale agent) and the type of market (incoming, outgoing or combined).

\section{Literature review}

Wu and Lee (2005) define e-communication as the "use of Internet technologies to link customers, suppliers, business partners and employees using intranets, websites, extranets and IP electronic data interchange". Some organizations adopt electronic business proactively, while others go through the process in several stages. According to Lin and Lee (2005), the first and 
initial level consists of website implementation. In this stage, internet technology is used to access information and brochures. The move to the second level demands considerable investment needed to build e-business infrastructure and enable internal communication canals and data basis. The third level refers to networking with suppliers (travel wholesalers, hotels, airlines etc.), while the highest, fourth level, refers to the integration of whole business procedures and transforming the overall organizational business model.

Some researchers suggest that government should play an important role in protecting the entire mediator sector that is a large generator of working positions. Facilitating the use of e-business for the tourism industry can be accomplished through a partnership with the private sector (UNWTO 2001; OECD, 2000). According to Kim (2004), there are a number of barriers in the process of adopting e-business in SMTEs, such as: limited knowledge of available technology, lack of awareness, cost of initial investment, lack of confidence and cost of system maintenance. Possible barriers could also be a shortage of skilled human resources and resistance to the adoption of new technology. In the study conducted by Heung (2003), among 15 offered barriers, cost of implementation was noted as the most serious one. Other major factors were a shortage of well-trained staff, security concerns, hard to manage travel data and cost of education and training. The state must assume key role to overcome these barriers. According to the data of The Statistical Office of The Republic of Serbia (2010), the highest number of travel agencies in Serbia are micro-companies with less than 10 employees (88\%), small companies make $9 \%$ (10 to 49 employees), less than $2 \%$ of companies have 50 to 249 employees, while the number of travel agencies with over 250 employees is practically negligible. Mediator tourist agencies are predominantly small businesses owned by families (Štetić \& Dragičević, 2011). According to the latest labour force survey conducted in Serbia in 3rd quarter 2014, there is an estimated number of 1,357,140 people working in service sector (Krasulja et al., 2014).

As one of the most significant areas of electronic business, electronic trading was used by 1.16 million people in Serbia in the year 2014, which is by $28 \%$ higher compared to the previous year (Đelić, 2015). Unfortunately, Serbia is falling behind the European Union and is without a clear path in the development of e-trading, as shown by the research of A.T.Karni consultant house. In the research "Global index of e-trade development for the year 2015", it is stated that Serbia occupies the last place as it does not have a prepared plan for further development of electronic trading (newsweek. rs, 2015). In the countries of the European Union, over $70 \%$ of trading is done electronically. The application of electronic signature and electronic business changes the business environment and creates the conditions to conduct all businesses more quickly, efficiently and economically. The most widespread service of electronic business in Serbia is e-banking, and the future of the development of e-business in Serbia depends on the rate of the development of electronic trading, which deals in providing service. The barriers that hinder the development of electronic business are quite slowly being removed, even though fast internet has been more widespread, law regarding e-signature has been passed and the work on the national strategy for the development of information society has begun, in which electronic business has been recognised as one of the priorities (Radivojević, 2014). In Serbia, the dominance of local tourist agencies of emissive character is obvious, as confirmed by the data of The Statistical Office of Serbia (2010). Namely, in 2009, in the arrangement of tourist agencies, almost 580,000 local tourists travelled abroad and about 216,000 local tourists resided in Serbia, while only 27,000 foreign tourists visited Serbia through the arrangements of tourist agencies (Štetić \& Dragičević, 2011). Tourist agencies included in the research conducted in Serbia by Štetić and Dragičević (2011) utilise at least one reservation system, electronic mail and have their own web presentation. However, five tourist agencies do not have their own web presentation, and as much as $25 \%$ of tourist agencies do not provide the possibility of on-line inquiry and service reservation to the potential clients, which, in the era of the internet and the increasing importance of electronic business, is practically intolerable. 


\section{Research methodology}

In this study measurement for the e-business was developed in several stages. An initial poll of items was generated from literature search. In addition to that, indepth interviews were also conducted with employees in travel agencies, the main purpose being to generate e-business usage items that were specific in the Serbian context. A total of 21 items were generated from these sources after taking into account identical or equivalent items. These items were then refined and edited for content validity by a group of three expert judges who are academics with research interest in tourism. Finally, a set of 16 items was taken into account. All these items were measured on a five-point scale ranging from 1 (strongly disagree) to 5 (strongly agree). A questionnaire was employed as the main method of data collection.

Software package SPSS 20. was used for the data analysis. E-business usage was calculated as the mean score of the items. Factor analysis was applied to the set of online business items for the purpose of obtaining the underlying dimensions or factors, and a Cronbach Alpha coefficient was used to test the reliability of the model. The distribution of data differed significantly from the normal distribution (Kolmogorov-Smirnov test, $p<0.05$ ), so it was used Kruskal Wallis test and Mann-Whiteney $U$ test to check the differences in implementation of e-business depending on the characteristics of the travel agencies: years in business, the type of licencing (tour operator or subagent) and the type of market.

Table 1. Sample description

\begin{tabular}{lc}
\hline & Years in business \\
\hline $1-10$ years & $58.5 \%$ \\
$11-20$ years & $13.8 \%$ \\
$21-30$ years & $15.4 \%$ \\
$31-40$ years & $3.1 \%$ \\
$41-50$ years & $9.2 \%$ \\
\hline Tour operator & \\
\hline Agent & $87.7 \%$ \\
\hline The type of agency according to the type of market \\
\hline Outgoing & $12.3 \%$ \\
\hline Incoming & $41.5 \%$ \\
\hline Mixed licence owned by the agency & $1.5 \%$ \\
\hline
\end{tabular}

The research was conducted during February and March of 2015. The largest number of questionnaires was distributed at the Belgrade Tourism Fair, where a large number of tourist agencies and tour operators from the whole territory of Serbia were doing promotion. Also, questionnaire distribution was conducted via e-mail, where the representatives of the agencies were asked to fill in the questionnaire and return it to the sender. Finally, the sample included 65 different tourist agencies and tour operators. Research methodology should unambiguously describe the process of collection and processing (including statistical methods) of data used in the research with all necessary information needed for repeated investigation.
Over a half of surveyed agencies have a relatively short period of operation in the market, up to 10 years (58.5\%). The sample is dominated by travel organisers $(87.7 \%)$, and as far as the type of market they are focused on, $41.5 \%$ consists of initiative organisations. In Serbia, which is still in the process of "opening" towards foreign markets, a small number of agencies that are exclusively of receptive type currently operate, so for that reason the sample only shows $1.5 \%$ of agencies that are declared as receptive. 


\section{Research results}

- Dimensions of e-business usage in travel agencies

Factor analysis with Varimax rotation was performed on the 16 items of online business of travel agencies and tour operators to determine the underlying dimensions of online business.

A total of four factors with eigenvalue of more than 1 were extracted from the factor analysis. Two out of the 16 items were not considered in the final model because of cross-loadings between dimensions. All the four factors that emerged from 14 items explained $62.2 \%$ of the total variance. The resultant Kaiser-MeyerOlkin (KMO) measure of sampling adequacy was 0.689 and the Bartlett's test of sphericity is significant ( $\operatorname{sig}=0.000$ ) which illustrates that the items for online business measure were appropriate for the factor analysis. All resultant factor loadings for the items were recorded to be between 0.51 and 0.84 .

The first dimension was labelled as "Online communication" and it explained $31.9 \%$ of

Table 2. Cronbach Alpha and Factor analysis of online business in travel agencies

\begin{tabular}{|c|c|c|c|c|}
\hline & $\begin{array}{l}\text { Cronbach } \\
\text { alpha }\end{array}$ & Eigenvalue & Factor loading & $\begin{array}{l}\text { Percentage of } \\
\text { variance }\end{array}$ \\
\hline Factor 1: Online Communication & 0.777 & 4.473 & & 31.948 \\
\hline Online communication is more frequent than direct & & & 0.840 & \\
\hline Online communication is more frequent than telephone & & & 0.723 & \\
\hline $\begin{array}{l}\text { Communication related to travel is most preferably done by } \\
\text { clients via social networks. }\end{array}$ & & & 0.611 & \\
\hline $\begin{array}{l}\text { Communication related to travel reservations is done by clients } \\
\text { via e-mail. }\end{array}$ & & & 0.604 & \\
\hline Clients would prefer to pay electronically. & & & 0.571 & \\
\hline Factor 2: Online promotion & 0.707 & 1.819 & & 12.996 \\
\hline The clients are notified about new offers and sales via website. & & & 0.823 & \\
\hline Clients are notified via new offers and sales via social networks. & & & 0.732 & \\
\hline $\begin{array}{l}\text { Photographs and comments of travellers are published on the } \\
\text { website and social networks. }\end{array}$ & & & 0.626 & \\
\hline $\begin{array}{l}\text { Spending money for computers, equipment and education is } \\
\text { considered an investment. }\end{array}$ & & & 0.613 & \\
\hline Factor 3: Impact on sales & 0.517 & 1.334 & & 9.526 \\
\hline $\begin{array}{l}\text { E-communication and on-line marketing expand the circle of } \\
\text { potential clients. }\end{array}$ & & & 0.719 & \\
\hline Surveys via website are increasingly more common. & & & 0.553 & \\
\hline We keep record about the effects of online marketing on sales. & & & 0.510 & \\
\hline Factor 4: Working hours reduction vs. sales improvement & 0.631 & 1.091 & & 7.793 \\
\hline $\begin{array}{l}\text { Electronic communication enables the shortening of working } \\
\text { hours. }\end{array}$ & & & 0.771 & \\
\hline We occasionally organize giveaways and quizzes. & & & 0.746 & \\
\hline
\end{tabular}


the total variance. The second dimension, which explained $12.9 \%$ of the total variance, was named "Online promotion". "Impacts on sales" was the third dimension of the model and it explained $9.5 \%$ of the variance. The last dimension was labelled as "working hours reduction vs. sales improvement" and it explained $7.7 \%$ of the variance

- E-business in Serbian travel agencies and differences according to the characteristics of an establishment
The arithmetic mean of 14 elements of online business in travel agencies was in the range of 2.48 to 4.37 . The highest levels of agreement was found in: "The clients are notified about new offers and sales via website", "E-communication and online marketing expand the circle of potential clients" and "Spending money on computers, equipment and education is considered an investment". Employees in travel agencies agree the least with the following statements: "Communication related to travel is most

Table 3. Evaluation of e-business usage and differences in relation to licensing, type of market and years in business of tourist agencies

\begin{tabular}{|c|c|c|c|c|c|c|c|c|}
\hline \multirow[b]{2}{*}{ Dimensions/Items } & \multicolumn{2}{|c|}{$\begin{array}{l}\text { E-business } \\
\text { evaluation }\end{array}$} & \multicolumn{2}{|c|}{ licencing } & \multicolumn{2}{|c|}{ type of market* } & \multicolumn{2}{|c|}{ years of business } \\
\hline & Mean & Std. Dev. & $\mathrm{U}$ test & Sig. & U test & Sig. & K-W test & Sig. \\
\hline Online communication & 3.38 & 0.878 & 180.0 & 0.336 & 608.0 & 0.139 & 3.850 & 0.427 \\
\hline $\begin{array}{l}\text { Online communication is more frequent than via } \\
\text { telephone }\end{array}$ & 3.74 & 1.065 & 189.0 & 0.417 & 476.5 & 0.745 & 7.150 & 0.128 \\
\hline $\begin{array}{l}\text { Online communication is more frequent than } \\
\text { direct }\end{array}$ & 3.46 & 1.251 & $\underline{129.5}$ & $\underline{0.042^{*}}$ & 571.0 & 0.316 & 4.007 & 0.405 \\
\hline Clients would prefer to pay electronically & 3.80 & 1.162 & 291.5 & 0.187 & 527.0 & 0.697 & 8.914 & 0.063 \\
\hline $\begin{array}{l}\text { Communication related to travel reservations is } \\
\text { done by clients via e-mail. }\end{array}$ & 3.46 & 1.187 & 143.5 & 0.082 & $\underline{648.5}$ & $\underline{0.037^{*}}$ & 5.082 & 0.279 \\
\hline $\begin{array}{l}\text { Communication related to travel is most } \\
\text { preferably done by clients via social networks. }\end{array}$ & 2.48 & 1.359 & 217.5 & 0.829 & 582.0 & 0.247 & 4.002 & 0.406 \\
\hline Online promotion & 4.039 & 0.845 & 307.5 & 0.087 & 480.5 & 0.994 & 3.713 & 0.446 \\
\hline $\begin{array}{l}\text { Clients are notified about new offers and sales via } \\
\text { website. }\end{array}$ & 4.37 & .894 & 286.0 & 0.193 & 506.0 & 0.921 & 5.607 & 0.230 \\
\hline $\begin{array}{l}\text { Clients are notified about new offers and sales via } \\
\text { social networks. }\end{array}$ & 3.93 & 1.130 & 283.5 & 0.242 & 524.5 & 0.719 & 3.675 & 0.452 \\
\hline $\begin{array}{l}\text { Photographs and comments of travellers are } \\
\text { published on the website and social networks. }\end{array}$ & 3.54 & 1.521 & 278.0 & 0.297 & 516.0 & 0.815 & 3.369 & 0.498 \\
\hline $\begin{array}{l}\text { Spending money on computers. equipment and } \\
\text { education is considered an investment. }\end{array}$ & 4.28 & .983 & $\underline{313.5}$ & $\underline{0.044^{*}}$ & 365.5 & 0.492 & 5.512 & 0.239 \\
\hline Impacts on sales & 3.943 & 0.830 & 173.5 & 0.272 & 553.0 & 0.463 & 5.254 & 0.262 \\
\hline $\begin{array}{l}\text { E-communication and online marketing expand } \\
\text { the circle of potential clients. }\end{array}$ & 4.29 & 1.057 & 295.0 & 0.133 & 387.5 & 0.089 & 4.135 & 0.388 \\
\hline $\begin{array}{l}\text { Surveys via website are increasingly more } \\
\text { common. }\end{array}$ & 4.12 & 1.053 & 202.5 & 0.301 & 587.5 & 0.320 & 6.632 & 0.157 \\
\hline $\begin{array}{l}\text { We keep record about the effects of online } \\
\text { marketing on sales. }\end{array}$ & 3.42 & 1.357 & $\underline{117.0}$ & $\underline{0.022^{*}}$ & 578.5 & 0.269 & 6.725 & 0.151 \\
\hline Working hours reduction vs. sales improvement & 2.846 & 1.348 & 212.0 & 0.166 & $\underline{661.5}$ & $\underline{0.027^{*}}$ & 1.149 & 0.886 \\
\hline $\begin{array}{l}\text { Electronic communication enables shortening of } \\
\text { working hours. }\end{array}$ & 2.86 & 1.540 & 143.0 & 0.082 & $\underline{701.0}$ & $\underline{0.005 * *}$ & 3.394 & 0.494 \\
\hline We occasionally organize giveaways and quizzes. & 2.83 & 1.616 & 208.0 & 0.680 & 565.5 & 0.354 & 1.179 & 0.785 \\
\hline
\end{tabular}

*Note: due to a small sample of receptive agencies, only an analysis of differences between initiative and mixed travel agencies and tour operators has been conducted. 
preferably done by clients via social networks", "We occasionally organize giveaways and quizzes" and "Electronic communication enables shortening of the working hours".

When it comes to the kind of licencing owned by the agency, significant differences in online business exist with statements: "Online communication is more frequent than direct", "Spending money on computers equipment and education is considered an investment" and "We keep record about the effects of online marketing on sales. Travel organisers agree significantly more with these statements than subagents.

Mann Whitney U test of an independent sample was conducted to test whether or not there is a significant difference between outgoing and mixed tourist agencies with regard to the implementation of online business. The results of the test, which are summarized in Table 4, indicated that significant differences exist in two items "Communication related to travel reservations is done by clients via e-mail“ and "Electronic communication enables shortening of working hours" Mixed tourist agencies evaluated these items significantly higher.

Kruskal Wallis test showed that there are no statistical differences in e-business depending on the years in business of travel agencies

\section{Discussion}

This study found that e-business usage in travel agencies is best explained by "e-communication". Based on this major finding, it can be argued that e-communication is the primary element of e-business use in travel agencies so far. It includes correspondence with clients and suppliers (business partners) via e-mails, live-chat platforms, mobile applications, SMS and other instant messaging services (Mišković, 2015).

Factor analysis revealed that "online promotion" is the second most important dimension in explaining e-business implementation. This kind of promotion includes any uploading of commercial content, starting from the content of the agency's website, to profiles on social networks, to paid advertising on sites of other business subjects (media, destinations, portals, associations of professions etc.)

The "impact on sales" was the third most influential dimension in explaining e-business services. As the free market allows the offer to be placed to an unlimited number of potential buyers and users, agencies that have good politics of online promotion and are proactive in terms of communication will have higher chances for the expansion of existing base of clients and a larger volume of sales.

The fourth dimension in explaining e-business usage is "working hours reduction vs. sales improvement". As online communication does not demand that all employees are physically present in a certain business environment in a certain time period, many agencies decreased their costs of business by turning from working in two shifts (08-20h) to working in one shift (9-17h) and thus reduced the number of employees and achieved savings on energetics. Furthermore, the cost of lease of expensive premises in high transient streets and malls is more often decreased by relocating the business premises into smaller objects in locations outside the city centre, where bills and lease are far more favourable. Many employees, especially women with obligations related to children, are more often working at home, as well as employees whose travel costs are high and demand a lot of time.

The results of factor analyses indicate that our model (14 statements) explains $62.2 \%$ of e-business of travel agencies. This means that there is still $37.8 \%$ of factors that influence the process of implementation of e-business that are not enveloped by this model and therefore, it would be useful for them to be the subject of research in future studies of this type. As far as the implementation of e-business is concerned, it was examined whether there are differences in its application in relation to the years in business, licencing and the market aimed by the tourist agency.

Differences in individual statements that can be analysed exist in three items in relation to licencing and in two items in relations to the type of market.

As far as the relation of implementation of e-business and the type of licencing is concerned, it showed that travel organisers agree significantly more 
with the statement that online communication in their agencies is more frequent than direct when compared to subagents. This can be explained with the tendency of a large number of mediator agencies to do business in smaller environments (villages, smaller towns and city outskirts), where the population has a habit to visit the agency personally, to be familiar with the agents who are frequently the owners or long term employees whom they trust. On the other hand, tour operators with a large number of employees do business in urban areas, often have a large fluctuation of work force, and are aiming at lowering the costs by any means necessary which is why more and more work procedures are transferred to online regime, and consequently it is logical that they come far less into direct contact with the buyers. The same refers to caring about the effects of online promotion on sales. As travel organisers, they are the ones that invest in marketing and agencies that deal with sales work with more tour operators, so when they invest into marketing, it is focused towards a narrower circle of potential buyers and advertises the agency as a company, not its individual products, which is why it is more difficult (or impossible) to keep record about the effects of marketing on individual products from the offer.

U-test of an independent sample showed that mixed tourist agencies gave a significantly higher evaluation to the items: "Communication related to travel reservations is done by clients via e-mail" and "Electronic communication enables shortening of working hours" when compared to outgoing travel agencies. This tendency can also be explained by a larger number of clients that are physically removed from the seller, while communication and shopping using the internet is far closer to them when compared to the population in Serbia.

\section{Conclusion}

In a time when travel agencies have to survive commission cuts and open internet market impact, only those that successfully adopt new business models can thrive. They must offer added value and carve out niche products or services such as tailor-made tours and support travel-related procedures (Tsai, Huang, \& Lin, 2005). Both online and offline travel agencies need to differentiate themselves in order to focus on niche tourism consumers, to be proactive, rather than waiting to be contacted and asked for an offer.

It is unavoidable that the nature of work of tourist agencies will change, but that they will completely disappear from the "scene" is not to be expected. The fear of being left behind the on-line competition drove the decisions of travel agents to adopt IT in their businesses and transform the working processes in order to adopt to the needs and expectations of modern consumers. Also, the reduction in commission paid by airlines has prompted them to streamline and adapt to new business models in order to guarantee their longterm profitability.

Research in the area of e-business has undoubtedly grown in recent years. However, not much research has been done on the topic of electronic business of tourist agencies. The goal of this research was to determine what electronic business of tourist agencies consists of, and whether it differs depending on its business characteristics. For that purpose, model EBusTour was developed, which determines the basic dimensions of electronic business of travel agencies. Those are: electronic communication, electronic promotion, impacts on sales and reduction of working hours compared to advancement of sales. As far as electronic business of travel agencies in Serbia is concerned, results of EBusTour model indicate that online promotion is the most applied. The effects on sales are also very significant. Lower grades were given (mean 2.48) to the segments of business which refer to the number of queries via Facebook, Twitter and other social networks (earlier it was mentioned that the most preferable channel was e-mail). There are still not enough strategic moves in the form of organising giveaways, quizzes and other animating content (mean 2.83), and it also shows that it will be a while before agencies shorten their working hours (2.86), if, in fact, the opposite does not occur where the working hours become $24 \mathrm{~h}$, as it can already be seen on the examples of chat platforms integrated in many sites. 
In order to extensively modernise the process of doing business in tourism, it is necessary to first conduct a serious campaign and education by educational and public institutions.

The basic obstacle in the conducting of this research is the relatively small sample of examinees. Namely, in Serbia, there is still a significantly large number of agencies that do not own a website. Amongst these, sales agents from smaller environments who have a small number of employees (1-3) are the most numerous, and who sell arrangements of tour operators and make profit out of (often very modest) provisions. As they serve an already existing base of regular clients, investment into creating and maintaining a website for them is too much of a cost and obligation. On a large gathering of tourist workers, as is The Belgrade fair of tourism, a significant number of agencies was present, but due to high prices of stand lease, a large number of them came as visitors, so the number of those available to be surveyed was relatively small. Also, on some stands the agency representatives did not wish or were not authorised to give information to interviewers.

The topic of this research is definitely very interesting and current. As the role of agencies in the global tourist market changes and shifts from promotion and sales of packet arrangements or the collection of several tourist services to providing advice and mediation during payment and organising group travels, the topic of future research in this area can be focused on the changes in the number of permanently employed and comparing that number with sales volume, change of the volume and the structure of costs, changes in the employee structure, new occupations, new working positions and similar.

\section{REFERENCES}

Andreu, L., Aldas, J., Bigne, J., \& Mattila, A. (2010). An analysis of e-business adoption and its impact on relational quality in travel agency-supplier relationships. Tourism Management, 31, 777787.

Buhalis, D., \& Licata, M. (2001). The Future eTourism intermediaries. ENTER2001 conference. Montreal. Retrieved June 8, 2015, from http://epubs.surrey.ac.uk/1126/1/fulltext.pdf
Bush, M. (2000). Internet will not replace traditional reservation systems. Hotel and Motel Management, 215(17), 31.

Bush, M. (2001). Travel agents might be more important tha ever. Hotel and Motel Management, 216(19), 30.

Chu, R. (2001). What online Hong Kong travelers look for on airline/ travel websites? International Journal of Hospitality Management, 20(1), 95-100.

Đelić, J. (2015, May 26). http://www.naslovi.net/2015-05-26/ekapija. Retrieved September 14, 2015, from naslovi.net: http://www. naslovi.net/2015-05-26/ekapija/internet-menja-redove-i-tonepapira-elektronsko-poslovanje-u-porastu-nedostaju-jasnizakonski-okviri/14782641

Đelić, T. (2004). Internet i redefinisanje sistema distribucije u turizmu. Marketing, 35(3), 143-148. etourismnewsletter. (2002). Retrieved June 8, 2015, from http://www.etourismnewsletter.com/ ecommerceprint.htm

Heung, V. (2003). Internet usage by international travellers: reasons and barriers. Journal of Contemporary Hospitality Management, 15(7), $370-378$.

Kim, C. (2004). An innovative approach for the small and medium-sized tourism enterprises (SMTEs) in Korea. OECD.

Krasulja, N., Zubović, J., \& Radojević, I. (2014). Work-from-Home Impact on Income Satisfaction. Industrija, 42(3), 129-140.

Lin, H., \& Lee, G. (2005). Impact of organizational learning and knowledge management factors on e-business adoption. Management Decision, 43(2), 171-188.

Mišković, I. (2015). Komunikacija sa potrošačima u digitalnoj eri. U V. Zubanov, Procesi komunikacija sa potrošačima (str. 224-240). Novi Sad: Fakultet za sport i turizam.

newsweek.rs. (2015, May 07). newsweek.rs/biznis. Retrieved September 15, 2015, from newsweek.rs: http://www.newsweek. rs/biznis/49638-e-trgovina-srbija-poslednja-na-svetu.html

Organization for Economic Co-operation and Development (OECD). (2000). Realizing the potential of electronic commerce for SMEs in the glogal economy. Conference for Ministers responsible for SMEs and Industry Ministers. Bologna.

Radivojević, N. (2014, November 07). http://e-zanimljivosti.weebly. com/e-svet. Retrieved September 15, 2015, from e-zanimljivosti: http://e-zanimljivosti.weebly.com/e-svet/elektronskoposlovanje-je-nedovoljno-razvijeno-u-srbiji

Roger-Monzo, V., Marti-Sanchez, M., \& Guijarro-Garcia, M. (2015). Using online consumer loyalty to gain competitive advantage in travel agencies. Journal of Business Research, 68, 1638-1640.

Suarez, L., Diaz, A., \& Vazquez, R. (2007). Relationship marketing and information technologies: analysis of retail travel agencies. Journal of Travel Research, 45(5), 453-463. 
Štetić, S., \& Dragičević, V. (2011). Evaluacija turističkih agencija u Srbiji. Ekonomske teme, 1, 71-81.

Travel Agent. (2012, November 1). Travel Agent. Retrieved July 2, 2015, from Travel Agent: http://baptistebuonomo.blogspot. com/2012/11/different-types-of-travel-agencies.html

Tsai, H.-T., Huang, L., \& Lin, C.-G. (2005). Emerging e-commerce development for Taiwanese travel agencies. Tourism Management, 26, 787-796.

World Tourism Organization (WTO). (2001). E-business For Tourism, Practical Guideline For Tourism Destination and Business. WTO.

Wu, F., \& Lee, Y.-K. (2005). Determinants of e-communication adoption: the internal push versus external pull factors. Marketing Theory, 5(1), 7-31.

Datum prijave rada: 24.05.2016.

Datum prihvatanja rada: 07.07.2016.

\section{Kontakt}

Ivana Mišković, Fakultet za sport i turizam,

Novi Sad, Radnička 30a

E-mail: ivana.miskovic@tims.edu.rs

\section{Jelica Marković}

E-mail: jelica_ns@yahoo.com

Gordana Đurić, Srednja škola „Svetozar Miletić”, Novi Sad, Narodnih heroja 7

E-mail: gogadjuric14@gmail.com 